\title{
Algılanan Örgütsel Desteğin İşe Gömülmüşlük Üzerine Etkisi: Kişi-İş Uyumunun Aracilık Rolüi \\ (The Effect of Perceived Organizational Support on Job Embeddedness: Mediating Role of Person-Job Fit)
}

\section{Volkan MAZIOĞLU iD a Engin KANBUR iD $b$}

a Kastamonu Üniversitesi Sosyal Bilimler Enstitüsü İşletme, Kastamonu, Türkiye. volkanm8@gmail.com

b Kastamonu Üniversitesi Sivil Havacılık Yüksekokulu Havacılık Yönetimi Bölümü, Kastamonu, Türkiye. ekanbur@kastamonu.edu.tr

\begin{tabular}{|c|c|}
\hline MAKALE BİLGİSI & ÖZET \\
\hline Anahtar Kelimeler: & $\begin{array}{l}\text { Amaç - Bu çalışmanın amacı, algılanan örgütsel desteğin işe gömülmüşlük üzerindeki etkisinde } \\
\text { kişi-iş uyumunun aracılık rolünün incelenmesidir. }\end{array}$ \\
\hline $\begin{array}{l}\text { İşe Gömülmüşlük } \\
\text { Kişi-İş Uyumu }\end{array}$ & $\begin{array}{l}\text { Yöntem - Araştırma verileri, Kastamonu'da yer alan kamu ve özel bankalarda görev yapan ve } \\
\text { kolayda örnekleme yöntemi ile belirlenen } 274 \text { çalışandan anket tekniği ile toplanmış olup korelasyon } \\
\text { analizi, regresyon analizi ve hiyerarşik regresyon analizi ile test edilmiştir. }\end{array}$ \\
\hline $\begin{array}{l}\text { Gönderilme Tarihi } 30 \text { Nisan } \\
2020 \\
\text { Revizyon Tarihi } 31 \text { Mayıs } 2020 \\
\text { Kabul Tarihi } 15 \text { Haziran } 2020\end{array}$ & $\begin{array}{l}\text { Bulgular - Algılanan örgütsel desteğin kişi-iş uyumu ve işe gömülmüşlük ile alt boyutları (uyum, } \\
\text { bağ ve fedakârlık) üzerinde pozitif ve anlamlı bir etkisi olduğu belirlenmiştir. Kişi-iş uyumunun işe } \\
\text { gömülmüşlük ve alt boyutları (uyum, bağ ve fedakârlık) üzerinde pozitif ve anlamlı bir etkisi } \\
\text { olduğu tespit edilmiştir. Ayrıca algılanan örgütsel desteğin işe gömülmüşlük ve alt boyutları } \\
\text { üzerindeki etkisinde kişi-iş uyumunun kısmi aracıllk rolü olduğu sonucuna ulaşılmıştır. }\end{array}$ \\
\hline $\begin{array}{l}\text { Makale Kategorisi: } \\
\text { Araştırma Makalesi }\end{array}$ & $\begin{array}{l}\text { Tartışma - Örgütlerin başarılı olabilmesi, amaçlarına ulaşabilmesi ve varlıklarını sürdürebilmesi } \\
\text { için çalışanların örgüte sağladığı katkı ve sergilediği performans önemlidir. Bu nedenle örgütlerin } \\
\text { çalışanlarına verdiği değer, katkı ve destek de bu doğrultuda gereklidir. Çalışanın işiyle uyumlu } \\
\text { olması ve yaptı̆̆ı işle yetenekleri arasındaki uyum işini daha özverili ve severek yapmasını } \\
\text { sağlayacaktır. Örgütte kişi-iş uyumunun tam olarak sağlanması çalışanın işiyle bütünleşmesini, } \\
\text { işine bağlanmasını ve işe gömülmesini sağlayacaktır. }\end{array}$ \\
\hline
\end{tabular}

\begin{tabular}{|c|c|}
\hline ARTICLE INFO & ABSTRACT \\
\hline & $\begin{array}{l}\text { Purpose - Purpose of this study was to investigate the mediating role of person-job fit in the effect } \\
\text { of organizational support on job embeddedness. }\end{array}$ \\
\hline $\begin{array}{l}\text { Support } \\
\text { Job Embeddedness } \\
\text { Person-Job Fit }\end{array}$ & $\begin{array}{l}\text { Design/methodology/approach - The research data were collected by using questionnaire } \\
\text { technique from } 274 \text { employees working at the public and private banks located in Kastamonu, which } \\
\text { were determined by convenience sampling and tested with correlation analysis, regression analysis } \\
\text { and hierarchical regression analysis. }\end{array}$ \\
\hline $\begin{array}{l}\text { Received } 30 \text { April } 2020 \\
\text { Revised } 31 \text { May } 2020 \\
\text { Accepted } 15 \text { June } 2020\end{array}$ & $\begin{array}{l}\text { Findings - It was revealed that perceived organizational support has a positive and significant effect } \\
\text { on person-job fit and job embeddedness with its subdimensions (fit, links and sacrifice). It was found } \\
\text { that person-job fit has a positive and significant effect on job embeddedness and its subdimensions } \\
\text { (fit, links and sacrifice). In addition, it was concluded that person-job fit has a partial mediating role } \\
\text { in the effect of perceived organizational support on job embeddedness and its subdimensions. }\end{array}$ \\
\hline Research Article & $\begin{array}{l}\text { Discussion - The contributions of the employees to the organization and the performance they show } \\
\text { are very important for the organizations to be successful, to reach their goals and to survive. For this } \\
\text { reason, the value, contribution and support which organizations give their employees is required in } \\
\text { this direction. The compliance of the employee with his/her job and the harmony between his/her } \\
\text { talents and job will enable him/her to do his/her job more devotedly and lovely. Ensuring full } \\
\text { person-job fit within the organization will contribute to the integration, commitment and } \\
\text { embeddedness of the employee to his/her job. }\end{array}$ \\
\hline
\end{tabular}

${ }^{1}$ Bu makale Volkan MAZIOĞLU'nun yüksek lisans tezinden türetilmiştir.

\section{Önerilen Atıf/Suggested Citation}

Mazıoğlu, V., Kanbur, E. (2020). Algilanan Örgütsel Desteğin İşe Gömülmüşlük Üzerine Etkisi: Kişi-İş Uyumunun Aracıllk Rolü, İşletme Araştırmaları Dergisi, 12 (2), 1639-1654. 


\section{GİRIŞ}

Örgütler, amaçlarına ulaşabilmek ve bunu sürdürülebilir kılmak için çalışanlarının yüksek düzeyde performans sergilemesine ve örgüte bağlılıklarına ihtiyaç duymaktadır. Örgütün bunu sağlayabilmesi çalışana ne kadar destek verdiği ve çalışanın bu desteği ne kadar algilayabildiği ile doğru orantılıdır. Algılanan örgütsel destek, çalışan ile örgüt arasındaki ilişkinin kalitesini göstermektedir. Bu ilişkinin kaliteli olması, çalışanın işine daha çok bağlanmasına ve örgütün yararını düşünen çalışanlar olarak görülmesine olanak sağlamaktadır (Yürür, 2005: 96). Yönetim alanında yapılan araştırmalar bireylerin neden çalıştıkları, neden performans sergilemek konusunda motive oldukları ve neden örgütte kalmak istedikleri üzerinde durmaktadır. Bu ilgili konular araştırmacıları çalışanların iş başarılarına etki eden nedenler hakkında çalışmalar yürütmeye yöneltmiştir. İşe gömülmüşlük, literatürde bu nedenlerden biri olarak üzerinde durulan bir kavramdır. İşe gömülmüşlük, ilk olarak Mitchell ve arkadaşları tarafından 2001 yılında ortaya konulmuş ve "İnsanlar neden kalır" ve "neden ayrılır" sorularını işletme yazınında cevap bulunmaya çalışılmıştır. Örgütler açısından diğer önemli bir konuma sahip olan kişi-iş uyumu ise kişi-çevre uyumu teorisi kapsamında düşünülmektedir. Örgütler artan rekabet şartlarına karşı varlıklarını sürdürebilmek, hedeflerine ulaşabilmek için işiyle uyum sağlayan nitelikli çalışanlara ihtiyaç duymaktadır. Bundan dolayı kişi-iş uyumu kavramı önem kazanmış ve çalışanın işiyle uyum sağlaması yaptığı işle yeteneklerinin uyuşması işini daha özverili ve severek yapmasını sağlamıştır (Kristof, 1996: 1).

Bu çalışmanın iki temel problemi bulunmaktadır; birincisi, algılanan örgütsel desteğin işe gömülmüşlük üzerindeki etkisinin ortaya çıkarılmasıdır. İkincisi ise, çalışanın örgütsel destek algılarının işe gömülmüşlük düzeyleri üzerindeki etkisinde kişi-iş uyumunun aracılık rolünün olup olmadığının ortaya konulmasıdır. Çalışmanın özellikle ikinci problemini ortaya çıkarmak için detaylı bir yazın taraması yapılmıştır. Yazın taraması sonucunda algılanan örgütsel desteğin işe gömülmüşlük üzerine etkisinde kişi-iş uyumunun aracıllk rolünü inceleyen herhangi bir çalışmaya rastlanmamıştır. Dolayısıyla yazında aracılık rolünün incelenmediği düşünüldüğünde bu çalışmanın yazına katkıda bulunacağı açıktır. Bu kapsamda, çalışmanın amacı; algılanan örgütsel desteğin işe gömülmüşlük üzerindeki etkisinde kişi-iş uyumunun aracılık rolünün olup olmadığının tespit edilmesidir.

\section{KAVRAMSAL ÇERÇEVE}

\subsection{Algılanan Örgütsel Destek}

Örgütsel destek, örgütün çalışanlarına nasıl bir katkı sağladığını ve onların refahını ne ölçüde etkilediğine ilişkin çalışanların inançları olarak tanımlanabilir. Bu inançlar çalışanın örgüt ile yaşadığı deneyimler ve etkileşimler sonucunda gelişmektedir (Rhoades, Eisenberger ve Armeli, 2001: 825). Örgütlerde, çalışanların görevlerini verimli bir şekilde yapabilmeleri için; istek, zaman, temin edilen yenilik, örgüt tarafından sağlanan destek, insan kaynakları yönetimi yöntem ve işlemleri gibi etkenler önemli bir yer tutmaktadır (Bredin ve Söderlund, 2007: 816). Bireyler, hayatları boyunca başkaları tarafından desteklediğini bilmesi kendilerini iyi hissetmelerini sağlar. Bu doğrultuda bireyler ömürlerinin büyük bölümünü çalışarak geçirdiğinden örgüt tarafından desteklendiğini hissetmesi oldukça önem taşımaktadır (Çalışkan ve Pekkan, 2017: 21). Çalışanların iş esnasında en doğru kararları almaları ve muhtemel yanlışların giderilmesi için örgütsel olarak devamlı ve düzenli bir şekilde desteklenmeleri gerekir (Whittaker ve Marchington, 2003: 251). Destekleyici bir örgüt, çalışanların istek ve beklentilerini dikkate almalı ve onlara değerli olduğunu hissettirmelidir (Shore ve Tetrick, 1991: 637). Çünkü örgütsel desteğin hem örgüte hem de çalışanlara sağladığı birçok faydası vardır. Bunlardan biri de çalışanın iş tatminini güçlendirmesidir (Allen, Shore ve Griffeth, 2003: 100).

İşörenlerin örgüt ve yöneticiler tarafından kendine gösterilen önemi algılama biçimi algılanan örgütsel destek ile anlam bulmaktadır (Eisenberger, Huntington, Hutchison ve Sowa, 1986: 501). Diğer bir ifadeyle; algılanan örgütsel destek, çalışanların örgütün amaçlarına ulaşmasında sağladığı katkılardan dolayı örgüt ve üst yönetim tarafından ödüllendirilmeyi beklediği sosyal bir süreçtir (Kurtessis, Eisenberger, Ford, Buffardi, Stewart ve Adis, 2015: 2). Algılanan örgütsel destek, çalışanların örgüt tarafından değer görmesi, yönetimin ve örgütün desteğini almasıdır (Turunç ve Çelik, 2010: 184). Diğer bir tanıma göre algılanan örgütsel destek, bireyin örgüt içinde amaçlarını gerçekleştirebilmesi için harcadığı emek ve verdiği katkı neticesinde, örgütün de bireye verdiği maddi ve manevi destek olarak tanımlanabilir (Eisenberger, Jones, Aselage ve Sucharski, 2004: 565; Kanbur, 2016: 446). Algılanan örgütsel destek, yöneticiler tarafından çalışanların fikir ve düşüncelerine önem verilmesini konu edinen ve araştırmacılar tarafından kabul görmüş düşünceleri 
açıkladığı için önemlidir (Zagenczyk, 2001: 13). Algılanan örgütsel destek, çalışanın zor durumda kaldığında örgütün yanında olacağına ve destek vereceğine olan inancıdır. Fakat çalışanlar, örgütün güven ve desteğini almadıklarında işten ayrılma gibi düşüncelere kapılabilirler (Kaya, 2013: 4). Örgütsel desteğin bir diğer önemi ise çalışanların iş tatminini artırmasıdır. Bu durum çalışanların yaptıkları işten aldıkları tatmini artırmakta ve pozitif bir bakış açısı edinmelerine yardımcı olmakta ve işten ayrılma niyetlerini azaltmaktadır (Akkoç, Çalışkan ve Turunç, 2012: 108).

\section{2. İşe Gömülmüsşük}

Gömülmüşlük kavramı (embeddedness) literatüre ilk olarak Granovetter tarafından 1985 yılında kazandırılmış olup sosyoloji alanında, sosyal bağlantıların ekonomik etkenler üzerinde nasıl bir değişiklik yarattığını göstermek için kullanılmıştır (Candan, 2016: 72). Gömülmüşlük kavramı sosyolojide insanların birbirleriyle olan etkileşimlerini açıklarken, örgüt açısından kişinin kalma ya da ayrılma niyeti ile ilişkilendirilebilir (Yao, Lee, Mitchell, Burton ve Sablynski, 2004: 157). İşe gömülmüşlük kavramı ise ilk olarak Mitchell, Holtom, Lee, Sablynski ve Erez (2001) tarafından ortaya konulmuş ve "insanlar neden kalır" ve "neden ayrılır" problemlerini işletme literatüründe cevaplandıran bir kavram olmuştur. İşe gömülmüşlük, çalışanların örgütteki mevcut görevlerini bırakmalarını engelleyen bir yapı şeklinde ifade edilir (Lee, Mitchell, Sablynski, Burton ve Holtom, 2004: 712). İşe gömülmüşlük, çalışanların işlerine devam etmelerine olanak sağlayan unsurların tümü olarak tanımlanabilir (Birsel, Börü, İslamoğlu ve Yurtkoru, 2012: 52). İşe gömülmüşlük çalışanların işiyle, örgütüyle bütünleşmesindeki ve işine devam etmek istemesindeki nedeni ortaya koyan bir kavramdır (Akgündüz, Güzel ve Harman, 2016: 352). İşe gömülmüşlüğün çalışanın örgütle devam etmesini veya örgütle ilişkisine son vermesini etkileyen bir kavram olduğu üzerinde de durulmuştur (Bergiel, 2009: 206).

İşe gömülmüşlük; kişinin performansı ve işe katılımını sağlamada iş tatmini, örgütsel bağlılık, örgütsel adalet gibi psikolojik unsurlardan daha etkili olan belirleyici bir faktör olarak vurgulanmaktadır (Holtom, Mitchell ve Lee, 2006: 318). İşe gömülmüşlük örgütsel ve toplumsal açıdan kişilerin tutum ve davranışlarını açıklamada oldukça önem arz etmektedir (Sekiguchi, Burton ve Sablynski, 2008: 763-764). Bireylerin örgütlerde ve örgüt dışındaki yaşantılarında kendilerine göre kurallarının olduğu ve bu kurallara bağlı kaldıkları bir alanları vardır. İşe gömülü olma kavramı da bir çeşit bağdır. Bu bağ kişinin işi ve örgütü ile arasında kurduğu etkileşim sonucu ortaya çıkar. Kişi örgütle kendi arasında kurduğu bu bağ sayesinde işine olan sadakatini ve performansını daha iyi gösterebilmektedir (Mitchell vd., 2001: 1104). İşe gömülmüsslük düzeyi yüksek olan kişilerde, kişi işten ayrılma durumu olduğunda çok şey kaybedeceğini düşünüyorsa kişideki işe gömülmüşlük seviyesi yüksek olmakta, performansı ve işe katkıları artış göstermektedir (Bitmiş, Rodopman, Üner ve Sökmen, 2015: 5).

İşe gömülmüşlüğün boyutları üç şekilde incelenmektedir. Bunlar; uyum boyutu, fedakârlık boyutu ve bağ boyutu olarak ele alınmaktadır (Oyler, 2007: 95). Bağ boyutu, çalışanların; örgütler, kurumlar veya diğer bireylerle aralarında gerçekleşen resmi veya resmi olmayan ilişkileri olarak adlandırılır. İşe gömülmüşlük çalışanı, ailesini ve çevresini, sosyal, fiziksel, psikolojik ve finansal ağlarla kurduğu ilişkileri olumlu yönde etkiler (Büyükbeşe ve Gökaslan, 2018: 137). Uyum, çalışanların bulundukları örgütle ve çevreyle kendisini uyum içinde görmesi olarak belirtilir. İşgörenlerin sahip olduğu bireysel değerleri ve kariyer hedefleri; çalışma deneyimi, işiyle ilgili bilgi durumu ve yaptığı işin gereksinimleri birey ile örgüt arasındaki uyumun unsurları olarak kabul edilir (Akgündüz vd., 2016: 352). Fedakârlık boyutu ise, kişinin çalıştığı işten ayrılması durumunda maddi ve manevi olarak nelerden vazgeçebileceğine odaklanmaktadır. Bu kayıplar işyeri arkadaşlarından ayrılmak, örgütten ayrılmak, kariyer sağlayacak projelerden vazgeçmek, ödüllendirilme ve ikramiyelerden vazgeçmek gibi kişisel kayıplara sebep olmaktadır (Mitchell vd., 2001: 1103).

\subsection{Kişi-İş Uyumu}

Kişi-iş uyumu kişi-çevre uyumu kuramına dayanmaktadır. Çalışanlar iş yaşamları boyunca uyum arayışı içinde olmaktadır. Uyum, bireyin bilgi, yetenek ve kabiliyetleri ile iş için gerekli olan becerilerin birbiriyle düzen içinde olmasıdır. Kişi-çevre uyumu kişilerin bulunduğu konumlarına göre özellikleri eşleştiği zaman ortaya çıkan uyumluluk oranı olarak açıklanmıştır (Edwards, 1996: 3-4). Kişi-çevre uyumu, kişilerin iş konumuna göre özellikleri eşleştiği zaman ortaya çıan uyumluluk oranı olarak da açıklanmaktadır. Kişiçevre uyumu örgütsel psikolojide önemli bir yer tutmaya başlamıştır (Ulutaş, 2010: 28). İkinci Dünya Savaşı sona erdikten sonra örgütsel davranışı tanımlayan temel düşünce "kişinin işe uyum göstermesi" ve "işin 
kişiye uyum göstermesi" olmuştur. Çevresiyle yeterince uyumlu olan bireylerin işlerinde daha mutlu oldukları ve daha fazla verim sağladıkları görülmüştür (Uysal-Irak, 2012: 13).

Kişi-iş uyumu genel olarak, kişiler ve örgütler arasındaki uyum olarak ifade edilmiştir (Kristof, 1996: 3). İşin özelliklerinin kişiyle uyumlu olması işin özveriyle ve hızlı bir biçimde yapılmasına olanak sağlamaktadır. Uyum sağlanamadığında ise kişi daha fazla stres altına girmekte ve hata yapma olasılığı artmaktadır (Kılıç ve Yener, 2015: 163). Sekiguchi (2004) kişi-iş uyumunu, bireyin sahip olduğu yetenekleri ile işin gereksinimlerinin uyumu veya bireyin talepleriyle işin gerektirdikleri arasındaki uyum olarak açıklamıştır. Kişi iş uyumu, kişilerin üst düzey gereksinimleri ile iş özelliklerinin ve yeteneklerinin birbiriyle bağdaşmasıdır (Lauver ve Kristof-Brown, 2001). Bireylerin işleri ile uyumlu olması, iş performansları ve kariyer başarılarıyla ilgilidir (Uçanok, 2008: 25). Edwards (1991)'a göre kişi iş uyumu, birey taleplerini (ihtiyaçlar, amaçlar, değerler, ilgiler ve tercihler) çalıştığ ${ }_{1}$ işte buluyorsa; bunlar, mesleki nitelikler, iş gereksinimleriyle ilgili olan performans kriterleri, kişinin yetenekleriyle ilgili olan beceri, deneyim, eğitim gibi faktörler iş tarafından karşılanıyorsa kişi iş uyumu oluşur. Kişi iş uyumu bireylerin kişilik özellikleri ile çalıştığ kurumdaki görevinin birbirine uyum sağlaması olarak tanımlanır (Ulutaş, 2010: 29). Kişi iş uyumu yapılacak işler için doğru nitelikte kişileri işe alarak onların örgüt kültürüne uyumunun sağlanmasıdır (Shane, 2010: 200; Çelebi ve Ülker, 2013: 137).

\subsection{Kuramsal Alt Yapı ve Hipotez Geliştirme}

Algılanan örgütsel destek ile işe gömülmüşlük arasındaki ilişki Blau'nu Sosyal Mübadele Kuramı, Örgütsel Destek Kuramı ve Ekstra Rol Davranışı Kuramı tarafından açıklanabilir. Sosyal Mübadele Kuramı, bireylerin katkılarının ileride kendilerine geri döneceğine ve kazanç getireceğine dair beklentileri olarak tanımlanmaktadır (Cook ve Rice, 2003: 55). Örgütsel Destek Kuramı, örgütün çalışanlarına sağladığı destek verdiği değer neticesinde çalışanlarında örgütlerinden duyduğu memnuniyet ve bağlllık sonucunda örgütün yararına ve kazancına yönelik davranışlar sergilemesidir (Duygulu, Çıraklar ve Mohan, 2008: 109; Gavino, Wayne ve Erdoğan, 2012: 666). Ekstra Rol Davranışı Kuramı, örgütün verimliliğini ve performansını artırmak için çalışanların gönüllü olarak ortaya koydukları ve örgütsel amaçları destekleme, örgütün çıkarlarını her şeyin üzerinde tutma ve işi ile ilgili yenilikler sunma gibi rol ötesi olumlu davranışları içermektedir (Çetin ve Fıkırkoca, 2010: 43). Bu kuramsal altyapıyı destekler nitelikte yazında algılanan örgütsel destek ve işe gömülmüşlük arasındaki ilişkiyi ortaya koyan bazı çalışmalar bulunmaktadır. Allen ve Shanock (2012) 500 kişiden fazla çalışan ile yaptıkları araştırmalarında, algılanan örgütsel desteğin çalışanların işe gömülmüşlük düzeylerini anlamlı ve olumlu bir şekilde etkilediğini belirtmektedirler. Afsar ve Badir (2016) 673 otel çalışanı ve 131 yönetici ile yaptıkları araştırmalarında, çalışanların örgütsel destek algılarının yüksek olması ile onların işe gömülmüşlük düzeyleri arasında güçlü bir ilişkinin olduğunu belirtmektedirler. Aynı şekilde Akgündüz ve Şanlı (2017) otel çalışanları ile yürüttükleri araştırmalarında, algılanan örgütsel desteğin çalışanların işe gömülmüşlük düzeylerini olumlu yönde etkilediği sonucuna varmışlardır. Tabak ve Hendy (2016) algılanan örgütsel destek ile işe gömülmüşlük arasında pozitif yönlü bir ilişki olduğu sonucuna ulaşmıştır. Başka bir çalışmada ise Kesen ve Akyüz (2016) araştırmalarında elde ettikleri sonuçlara göre algılanan örgütsel desteğin çalışanların bağlamsal performans algılarını, işe bağlılıklarını arttırdığını ve çalışanların işe gömülmüşlük düzeylerini pozitif yönde etkileyerek işlerinden ayrılmalarını azaltabileceği sonucuna varılmıştır. Algılanan örgütsel destek arttıkça işe gömülmüşlük artacak ve işten ayrılma niyeti azalacaktır (Şanlı, 2016: 69).

H1: Algılanan örgütsel desteğin işe gömülmüşlük üzerinde pozitif ve anlamlı bir etkisi vardır.

H1a: Algilanan örgütsel desteğin işe gömülmüşlüğ̈̈n "uyum" boyutu üzerinde pozitif ve anlaml bir etkisi vardır.

$H_{1 b:}$ Algllanan örgütsel desteğin işe gömülmüşlü̆̆̈̈n "bă̆" boyutu üzerinde pozitif ve anlamlı bir etkisi vardır.

H1c: Algllanan örgütsel desteğin işe gömülmüşlüğ̈̈n "fedakârlı" boyutu üzerinde pozitif ve anlamlı bir etkisi vardır.

Örgütlerde verimliliğ̈in ve etkililiğin sağlanmasında kişi-iş uyumunun önemli bir rolü bulunmaktadır. Kişi-iş uyumu, bireylerin sahip olduğu yetenekleriyle işin gereksinimlerinin arasındaki uyuma denir (Sekiguchi, 2004: 184). Başarılı bir kişi-iş uyumu sayesinde kişisel isteklerin karşılanması, örgütsel adanmışlık, maddi ve manevi tecrübeler, iş tatmini, işe devamlılığın oluşması gibi birçok pozitif sonuçlara ulaşılır. Kişi-iş uyumu sayesinde ayrıca işin çekiciliği, motivasyonel artış, çalışanların değer kazanımı, tecrübe elde etmesi, performans düzeylerinde artış gibi birçok olumlu sonucu beraberinde getirir (Yazıcı, 2018, s. 10-11). Uyum sağlamadığında ise kişi daha fazla stres altına girmekte ve hata yapma olasılığı artmaktadır (Kılıç ve Yener, 2015: 163). Ancak iş gerekleri teknolojinin de gelişmesi ve değişmesiyle birlikte değişmekte ve 
farklılaşmaktadır. Örgütler değişen bu iş gereklilikleri karşısında çalışanlarının özelliklerini (bilgi ve tecrübe gibi) uyumlaştırmak için destek (güçlendirme, eğitim, geliştirme gibi) vermelidir. Yazında algılanan örgütsel destek ve kişi-iş uyumu arasındaki ilişkiyi ortaya koyan bazı çalışmalar bulunmaktadır. Cable ve DeRue (2002) çalışmalarında, algılanan örgütsel destek ile kişi-iş uyumu ile arasında pozitif yönlü ve anlamlı bir ilişkinin olduğunu tespit etmişlerdir. Aynı doğrultuda Chen (2010) çalışmasında, algılanan örgütsel destek ile kişi-iş uyumu arasında pozitif ve anlamlı bir ilişkinin olduğu sonucuna ulaşmıştır. Farrell ve Oczkowski (2009) büyük fast food işletmelerindeki 170 çalışan ile gerçekleştirdikleri araştırmalarında, algılanan örgütsel destek ile kişi-iş uyumu arasında güçlü ve olumlu bir ilişkinin olduğunu belirtmektedirler. Tseng ve Yu (2016) sigorta satış temsilcileri ile yaptıkları çalı̧̧malarında, algılanan örgütsel destek ile kişi-iş uyumu arasında anlamlı ve pozitif bir ilişkinin olduğu görülmektedir. Aynı zamanda bu uyumun çalışanların işten ayrılma niyetleri üzerinde olumsuz bir etki yarattığı belirtilmektedir.

$\mathrm{H}_{2}$ : Algılanan örgütsel desteğin kişi-iş uyumu üzerinde pozitif ve anlamlı bir etkisi vardır.

İşe gömülmüşlük ve kişi-iş uyumu arasındaki ilişkiyi Kişi-Çevre Uyumu Kuramı açıklamaktadır. Kişi-çevre uyumu kuramı, bireyin özellikleri ve çalışma koşullarının nitelikleri arasındaki uyumu ifade eder ve çalışanları motive ederek onları olumlu tarafa yönlendirecek faktörlerin neler olduğunu açıklar (Kristof, Zimmerman ve Johnson, 2005: 283). Bu kuramın boyutlarından olan kişi-iş uyumu, çalışanların bilgi, beceri ve yetenekleri ile biçimsel iş gerekleri arasındaki uyumluluk olarak açıklanır. Kişi-iş uyumu, işin talepleri ile kişinin yetenekleri arasındaki uyum (talep-yetenek uyumu) ve işin özellikleri ile kişinin arzuları arasındaki uyum (arz-ihtiyaç uyumu) olarak iki aşamada incelenmektedir (Aktaş, 2011: 15). Kişi- iş uyumu kuramına göre kişilerin mevcut özellikleri (bilgi, tecrübe, yetenek, deneyim vb.) ile iş gereksinimlerinin uyum sağlaması onların verimliliğini olumlu etkilemekte örgütsel bağlılık, iş tatmini ve iş performansı gibi pozitif örgütsel çıtıları ortaya koymaktadır (Kılıç ve Yener, 2015: 161). Çalışanların nitelikleri ile işin gereksinimleri ne kadar uyumlu olursa bu durum örgütsel çıktılara da olumlu olarak yansıyabilecektir. Bu bağlamda kişinin işiyle uyumlu olması durumu işe gömülmüşlük düzeyinde pozitif bir etki yaratabilir. Bu kuramsal altyapıyı destekler nitelikte yazında algılanan örgütsel destek ve işe gömülmüşlük arasındaki ilişkiyi ortaya koyan bazı çalışmalar bulunmaktadır. Kanten, Kanten ve Dündar (2016) çalışmalarında, iş özellikleri ile işe gömüşmüşlük arasında pozitif ve anlamlı bir ilişki olduğu sonucuna ulaşmışlardır. Bu iki uyum çalışanların mutluluk düzeylerini de arttırmaktadır. Coetzer, Inma ve Poisat (2017) Güney Afrika'da dört büyük işletmedeki 549 çalışan ile gerçekleştirdikleri çalışmalarında, kişi-iş uyumunun yüksek veya sağlanmış olması onların işe gömülmüşlük düzeylerini yükseltmekte, işten ayrılma niyetlerini ise buna bağlı olarak azaltmaktadır.

H3: Kişi-iş uyumunun işe gömülmüşlük üzerinde pozitif ve anlamlı bir ilişkisi vardır.

Hзa: Kişi-iş uyumunun işe gömülmüşlüğün "uyum" boyutu üzerinde pozitif ve anlamlı bir ilişkisi vardır.

Hзb: Kişi-iş uyumunun işe gömülmüşlüğ̈̈n "bă̆" boyutu üzerinde pozitif ve anlamlı bir ilişkisi vardır.

Hзc: Kişi-iş uyumunun işe gömülmüşlüğ̈̈n "fedakârllk" boyutu üzerinde pozitif ve anlamlı bir ilişkisi vardır.

Algılanan örgütsel destek, çalışanın örgütün yararına ve amaçları doğrultusunda çaba göstermesi, örgütün ise çalışanın çabasını ve katılımını önemsemesi ve desteklemesi (Kanbur, 2016: 446), kişi-iş uyumu ise, işin gereklilikleri ile kişinin özelliklerinin birbirine uyum göstermesidir (Sekiguchi, 2004, s. 184). Kişi-iş uyumu olmadığı takdirde işe gömülmüşlük oranı düşük olabilir (Lee vd., 2004: 712). Algılanan örgütsel desteğin işe gömülmüşlük üzerindeki etkisinde kişi-iş uyumunun aracılık rolünü inceleyen araştırmaya yazın taraması sonucunda rastlanmamıştır.

H4: Algılanan örgütsel desteğin işe gömülmüşlük üzerindeki etkisinde kişi-iş uyumunun aracllk rolü vardır.

H4a: Algllanan örgütsel desteğin işe gömülmüşlüğ̈̈n "uyum" boyutuna etkisinde kişi-iş uyumunun aracıllk rolü vardir.

H4b: Algilanan örgütsel desteğin işe gömülmüşlüğün "bă̆g" boyutuna etkisinde kişi-iş uyumunun aracıllk rolü vardır.

H4c: Algılanan örgütsel desteğgin işe gömülmüşlüğün "fedakârlık" boyutuna etkisinde kişi-iş uyumunun aracllk rolü vardir. 


\section{YÖNTEM}

\subsection{Araştırmanın Amacı ve Modeli}

Araştırmanın amacı, algılanan örgütsel desteğin işe gömülmüşlük üzerindeki etkisinde kişi-iş uyumunun aracılık rolünün incelenmesidir. Araştırmanın amacı kapsamında yapılandırılan araştırma modeli aşağıdaki Şekil 1'de sunulmaktadır.

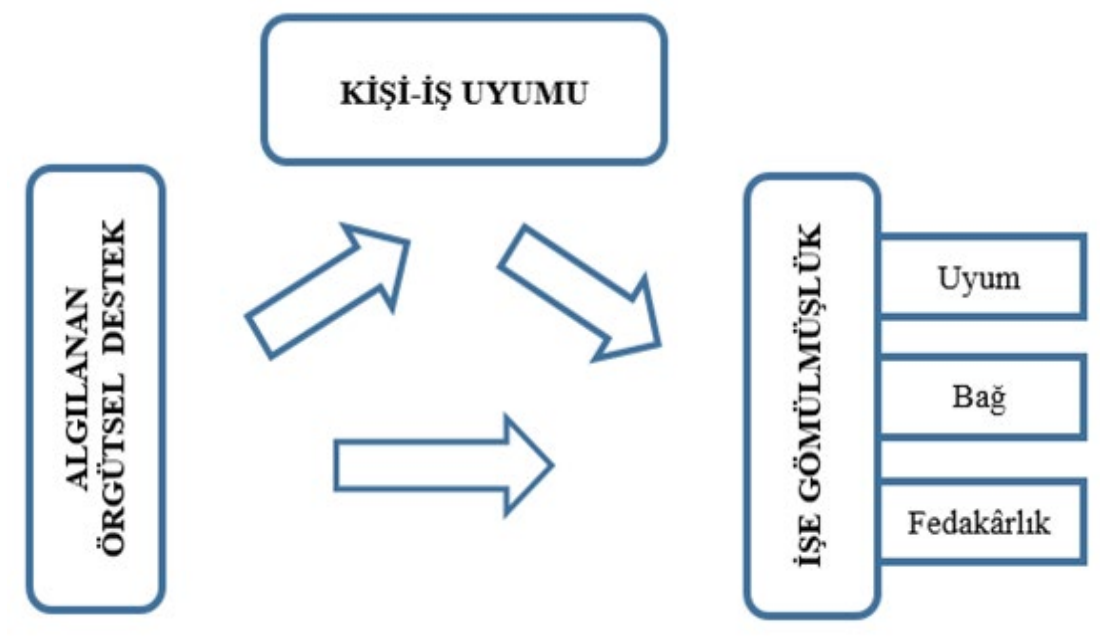

Şekil 1. Araştırma modeli

\subsection{Araştırmanın Evreni ve Örneklemi}

Araştırmanın evrenini, Kastamonu il merkezi ve ilçelerinde bulunan kamu, özel ve katılım bankalarındaki çalışanlar oluşturmaktadır. 2018 yılı Türkiye Bankalar Birliği verilerine göre, Kastamonu il merkezi ve 20 ilçesi dâhil olmak üzere toplam 573 banka çalışanı görev yapmaktadır (TBB, 2018). Bankacılık sektörünün iş yükü fazlalığı ve tüm ilçelere ulaşımın fiziksel zorlukları nedeniyle kolayda örnekleme yöntemi ile belirlenen toplam 310 banka çalışanına ulaşılmış, ancak bunlarda 285 banka çalışanından geri dönüş sağlanmıştır. Eksik ve yanlış doldurulan ve aynı zamanda güvenilirliği zedeleyici toplam 11 anket formu çıarıldıktan sonra evreni temsil kapasitesine sahip 274 kullanılabilir anket formu (Davis ve Cosenza, 1998: 28) veri analizlerine dâhil edilmiştir.

\subsection{Veri Toplama Tekniği ve Kullanılan Ölçekler}

Araştırmada hem analiz hem de yorum kolaylığı sebebi ile birincil veri toplama tekniği olan anket tekniğinden yararlanılmıştır. Araştırma verileri Mayıs-Haziran 2019 tarihleri arasında toplanmıştır. Ayrıca araştırmada verilerin toplanması amacıyla "Algılanan Örgütsel Destek Ölçeği", "İşe Gömülmüşlük Ölçeği" ve "Kişi-İş Uyumu Ölçeği" kullanılmıştır.

Araştırmada katılımcıların algılanan örgütsel destek düzeylerini belirlemek amacıyla Eisenberger, Huntington, Hutchison ve Sowa (1986) tarafından 36 maddelik uzun formu geliştirilen, Eisenberger, Cummings, Armeli ve Lynch (1997) tarafından kısa formu oluşturulan ve Lynch, Eisenberger ve Armeli (1999) tarafından çalışmalarında kullanılan geçerliği ve güvenirliği test edilmiş “Algılanan Örgütsel Destek ÖlçeğiPerceived Organizational Support Scale" kullanılmıştır. Ölçek tek boyuttan ve 8 maddeden oluşmaktadır. Algılanan Örgütsel Destek Ölçeği'nin yapısal geçerliğini incelemek üzere faktör analizi, güvenirliğini incelemek için ise iç tutarlılık analizi (Cronbach Alfa) gerçekleştirilmiştir (Tablo 1). 
Tablo 1. Algılanan örgütsel destek ölçeği için faktör ve güvenilirlik analizi bulguları

\begin{tabular}{lcccc}
\hline \hline Faktörler & $\begin{array}{c}\text { Madde } \\
\text { Sayıs }\end{array}$ & $\begin{array}{c}\text { Fak. Yük. } \\
\text { Aralığ1 }\end{array}$ & $\begin{array}{c}\text { Açıklanan } \\
\text { Varyans }(\%)\end{array}$ & $\begin{array}{c}\text { Cronbach } \\
\text { Alpha }(\alpha)\end{array}$ \\
\hline \hline Algılanan Örgütsel Destek & 8 &, $516-, 919$ & 62,127 &, 907 \\
$\begin{array}{l}\text { Kaiser-Meyer-Olkin (KMO): ,891 } \\
\text { Barlett: ki-kare=1695,003; df=28; } \mathrm{p}=, 000\end{array}$ & & & & \\
\hline
\end{tabular}

Araştırmada katılımcıların işe gömülmüşlük düzeylerini ölçmek amacıyla Mitchell, Holtom, Lee, Sablynski ve Erez (2001) tarafından ilk olarak geliştirilen, Ng ve Feldman (2009-2010) tarafından kısa formu oluşturulan ve Kanten, Kanten ve Dündar (2016) tarafından Türkçe'ye uyarlanan geçerliliği ve güvenilirliği kanıtlanmış “İşe Gömülmüşlük Ölçeği-Job Emdeddedness Scale" kullanılmıştır. Ölçek, 3 boyut ve 17 maddeden oluşmaktadır. Uyum (Fit) boyutunda 5 madde, Bağ (Link) boyutunda 5 madde ve Fedakârlık (Sacrifice) boyutunda ise 7 madde yer almaktadır. Ölçeğin yapısal geçerliğini incelemek üzere faktör analizi, güvenirliğini incelemek için ise iç tutarlılık analizi (Cronbach Alfa) gerçekleştirilmiştir (Tablo 2).

Tablo 2. İşe gömülmüşlük ölçeği için faktör ve güvenilirlik analizi bulguları

\begin{tabular}{lccccc}
\hline \hline Faktörler & $\begin{array}{c}\text { Madde } \\
\text { Sayısı }\end{array}$ & $\begin{array}{c}\text { Fak. Yük. } \\
\text { Aralığ }\end{array}$ & $\begin{array}{c}\text { Açıklanan } \\
\text { Varyans (\%) }\end{array}$ & Özdeğer & $\begin{array}{c}\text { Cronbach } \\
\text { Alpha }(\alpha)\end{array}$ \\
\hline \hline İse Gömülmüşlük & 17 &, $416-, 895$ & 60,083 & &, 898 \\
$\quad$ Uyum & 5 &, $694-, 754$ & 21,175 & 6,766 &, 868 \\
$\quad$ Bă̆ & 5 &, $416-, 895$ & 18,083 & 1,477 &, 793 \\
$\quad$ Fedakârlık & 7 &, $436-, 813$ & 20,826 & 1,971 &, 839 \\
$\begin{array}{l}\text { Kaiser-Meyer-Olkin }(\text { KMO): }, 882 \\
\text { Barlett: ki-kare=2388,373; } \mathrm{df}=136 ; \mathrm{p}=, 000\end{array}$ & & & & & \\
\hline
\end{tabular}

Araştırmada katılımcıların kişi-iş uyumu düzeylerini belirlemek amacıyla Saks ve Ashforth (1997) ile Hutcheson (1999) tarafından gerçekleştirilen çalışmalardan yararlanılarak Uysal-Irak (2014) tarafından Türkçe'ye uyarlanan geçerliliği ve güvenilirliği kanıtlanmış "Kişi-İş Uyumu Ölçeği-Person-Job Fit Scale"nin Ateş (2018) tarafından yürütülmüş olan çalışmadaki hali kullanılmıştır. Kişi-İş Uyumu Ölçeği, beş madde tek boyuttan oluşmaktadır. Kişi-İş Uyumu Ölçeği'nin yapısal geçerliğini incelemek üzere faktör analizi, güvenirliğini incelemek için ise iç tutarlılık analizi (Cronbach Alfa) gerçekleştirilmiştir (Tablo 3).

Tablo 3. Kişi-iş uyumu ölçeği için faktör ve güvenilirlik analizi bulguları

\begin{tabular}{lcccc}
\hline \hline Faktörler & $\begin{array}{c}\text { Madde } \\
\text { Sayısı }\end{array}$ & $\begin{array}{c}\text { Fak. Yük. } \\
\text { Aralığ1 }\end{array}$ & $\begin{array}{c}\text { Açıklanan } \\
\text { Varyans }(\%)\end{array}$ & $\begin{array}{c}\text { Cronbach } \\
\text { Alpha }(\alpha)\end{array}$ \\
\hline \hline Kişi-İş Uyumu & 5 &, $696-, 839$ & 63,139 & .852 \\
$\begin{array}{l}\text { Kaiser-Meyer-Olkin (KMO): }, 837 \\
\text { Barlett: ki-kare=575,738; } \mathrm{df}=10 ; \mathrm{p}=000\end{array}$ & & & & \\
\hline
\end{tabular}




\section{BULGULAR}

\subsection{Korelasyon Analizi}

Araştırmada algılanan örgütsel destek, işe gömülmüşlük ve boyutları ile kişi-iş uyumu arasında ilişkinin varlığını, ilişki varsa bu ilişkinin şiddetini ve yönünü ortaya koymak için korelasyon analizinden yararlanılmıştır (Tablo 4).

Değişkenlere ilişkin korelasyon analizine ilişkin bulgular incelendiğinde; algılanan örgütsel destek ile işe gömülmüşlük ( $\mathrm{r}=744 ; \mathrm{p}=.000)$ ve alt boyutlarından uyum $(\mathrm{r}=681 ; \mathrm{p}=.000)$, bağ $(\mathrm{r}=471 ; \mathrm{p}=.000)$ ve fedakarlık $(\mathrm{r}=660 ; \mathrm{p}=.000)$ ile kişi-iş uyumu ( $\mathrm{r}=683 ; \mathrm{p}=.000)$ arasında pozitif ve anlamlı bir ilişkinin olduğu görülmektedir. Ayrıca kişi-iş uyumu ile işe gömülmüşlük $(\mathrm{r}=658 ; \mathrm{p}=.000)$ ve alt boyutlarından uyum $(\mathrm{r}=635 ; \mathrm{p}=.000)$, bağ $(\mathrm{r}=458 ; \mathrm{p}=.000)$ ve fedakârlı $(\mathrm{r}=553 ; \mathrm{p}=.000)$ arasında da pozitif ve anlamlı bir ilişkinin varlığı görülmektedir.

Tablo 4. Korelasyon analizine yönelik bulgular

\begin{tabular}{|c|c|c|c|c|c|c|c|}
\hline \multicolumn{2}{|c|}{ Değişkenler } & \multirow{2}{*}{$\frac{1}{1}$} & \multirow[t]{2}{*}{2} & \multirow[t]{2}{*}{3} & \multirow[t]{2}{*}{4} & \multirow[t]{2}{*}{5} & \multirow[t]{2}{*}{6} \\
\hline 1 & Algılanan Örgütsel Destek & & & & & & \\
\hline 2 & İşe Gömülmüşlük & $744^{* *}$ & 1 & & & & \\
\hline 3 & Uyum & $681^{* *}$ &, $845^{* *}$ & 1 & & & \\
\hline 4 & $B a \breve{g}$ & , $471^{* *}$ &, $737^{* *}$ &, $535^{* *}$ & 1 & & \\
\hline 5 & Fedakârlık & $660^{* *}$ &, $870^{* *}$ &, $589^{* *}$ &, $416^{* *}$ & 1 & \\
\hline 6 & Kişi-İş Uyumu & $683^{* *}$ & $658^{* *}$ & ,635 &, $458^{* *}$ &, $533^{* *+}$ & 1 \\
\hline
\end{tabular}

${ }^{*} \mathrm{p}<0.01$ düzeyinde anlamlıdır.

\subsection{Regresyon Analizi}

Araştırma hipotezlerinin test edilmesi ve bulguların ortaya konulabilmesi için regresyon analizinden yararlanılmıştır (Tablo 5, 6, 7).

Tablo 5. Algılanan örgütsel destek ile işe gömülmüşlük ve alt boyutları arasındaki regresyon analizine yönelik bulgular

Bağımlı Değişken: Algılanan Örgütsel Destek

\begin{tabular}{|c|c|c|c|c|c|c|c|}
\hline Bağımsız değişken & $\mathbf{R}^{2}$ & Düz.R ${ }^{2}$ & $\mathbf{F}$ & $\beta$ & $\mathbf{t}$ & $\mathbf{p}$ & DW \\
\hline İşe Gömülmüşlük &, 554 &, 553 & $338,175^{*}$ & ,744 & 18,390 &, $000^{*}$ & 1,789 \\
\hline Uyum & 464 & ,462 & $235,120^{*}$ & 681 & 15,334 &, $000^{*}$ & 1,886 \\
\hline$B a \breve{g}$ & ,222 & 219 & $77,645^{*}$ & 471 & 8,812 &, $000^{*}$ & 1,802 \\
\hline Fedakârlık & ,435 & 433 & $209,502^{*}$ & 660 & 14,474 &, $000^{*}$ & 1,955 \\
\hline
\end{tabular}

${ }^{*} \mathrm{p}<0.01$ düzeyinde anlamlıdır. 
Tablo 5'te yer alan basit doğrusal regresyon analizi ve bulguları incelendiğinde, işe gömülmüşlügün \%55.3'ünün algılanan örgütsel destek tarafından açıklandığı (Düz. $\left.R^{2}=.554\right)$ ve modelin anlamlı ( $\mathrm{F}=338,175$; $\mathrm{p}=.000$ ) olduğu görülmektedir. Ayrıca işe gömülmüşlügün alt boyutlarından uyum boyutunun $\% 46.2^{\prime} \operatorname{sinin}$ (Düz.R²=.462; F=235,120; p=.000), bağ boyutunun \%21.9'unun (Düz.R ${ }^{2}=.219 ; \mathrm{F}=77,645 ; \mathrm{p}=.000$ ) ve fedakârlık boyutunun \%43.3'ünün (Düz.R²=.433; F=209,502; p=.000) algılanan örgütsel destek tarafından açıklandığ1 ve kurulan basit doğrusal regresyon modellerinin anlamlı olduğu görülmektedir. Bu bulgular ışığında araştırmanın birinci hipotezi $\left(\mathrm{H}_{1}\right)$ ve alt hipotezleri $\left(\mathrm{H}_{1 \mathrm{a}}, \mathrm{H}_{1 \mathrm{~b}}\right.$ ve $\left.\mathrm{H}_{1 \mathrm{c}}\right)$ desteklenmektedir.

Tablo 6'da yer alan basit doğrusal regresyon analizi ve bulguları incelendiğinde, kişi-iş uyumunun \%46,4'ünün algılanan örgütsel destek tarafından açıklandığı (Düz. $\left.R^{2}=.464\right)$ ve modelin anlamlı ( $\mathrm{F}=237,577$; p=.000) olduğu görülmektedir. Bu bulgular ışı̆̆ında araştırmanın ikinci hipotezi $\left(\mathrm{H}_{2}\right)$ desteklenmektedir.

Tablo 6. Algılanan örgütsel destek ile kişi-iş uyumu arasındaki regresyon analizine yönelik bulgular

Bağımlı Değişken: Algılanan Örgütsel Destek

\begin{tabular}{lccccccc}
\hline \hline Bağımsız değişsen & $\mathbf{R}^{2}$ & Düz.R ${ }^{2}$ & $\mathbf{F}$ & $\boldsymbol{\beta}$ & $\mathbf{t}$ & $\mathbf{p}$ & DW \\
Kişi-Iş̧ Uyumu &, 466 &, 464 & $237,577^{*}$ &, 683 & 15,414 &, $000^{*}$ & 2,021 \\
\hline \hline
\end{tabular}

${ }^{*} \mathrm{p}<0.01$ düzeyinde anlamlıdır.

Kişi-iş uyumu ile işe gömülmüşlük ve alt boyutları arasındaki regresyona analizi ve bulguları incelendiğinde, işe gömülmüşlüğün \%43.1'inin kişi-iş uyumu tarafından açıklandığı (Düz.R ${ }^{2}=.431$ ) ve modelin anlamlı ( $\mathrm{F}=207,797 ; \mathrm{p}=.000)$ olduğu görülmektedir. Ayrıca işe gömülmüşlügü̆n alt boyutlarından uyum boyutunun \%40.2'sinin (Düz.R ${ }^{2}=.402 ; F=184,183 ; p=.000$ ), bağ boyutunun \%20.7'sinin (Düz.R²=.207; F=72,348; $p=.000$ ) ve fedakârlık boyutunun \%28.2'sinin (Düz. $\mathrm{R}^{2}=.282 ; \mathrm{F}=108,117 ; \mathrm{p}=.000$ ) algılanan örgütsel destek tarafından açıklandığı ve kurulan basit doğrusal regresyon modellerinin anlamlı olduğu görülmektedir. Bu bulgular ışığında araştırmanın üçüncü hipotezi $\left(\mathrm{H}_{3}\right)$ ve alt hipotezleri $\left(\mathrm{H}_{3 a}, \mathrm{H}_{3 b}\right.$ ve $\left.\mathrm{H}_{3 c}\right)$ desteklenmektedir.

Tablo 7. Kişi-iş uyumu ile işe gömülmüşlük ve alt boyutları arasındaki regresyon analizine yönelik bulgular

Bağımlı Değişken: Kişi-İş Uyumu

\begin{tabular}{lccccccc}
\hline \hline Bağımsız değişken & $\mathbf{R}^{2}$ & Düz.R & $\mathbf{F}$ & $\boldsymbol{\beta}$ & $\mathbf{t}$ & $\mathbf{p}$ & $\mathbf{D W}$ \\
İşe Gömülmüşlük &, 433 &, 431 & $207,797^{*}$ &, 658 & 14,415 &, $000^{*}$ & 1,867 \\
\hline Uyum &, 404 &, 402 & $184,183^{*}$ &, 635 & 13,571 &, $000^{*}$ & 1,832 \\
\hline Bă̆ &, 2010 &, 207 & $72,348^{*}$ &, 458 & 8,506 &, $000^{*}$ & 1,879 \\
\hline Fedakârlık &, 284 &, 282 & $108,117^{*}$ &, 533 & 10,398 &, $000^{*}$ & 1,961 \\
\hline \hline
\end{tabular}

${ }^{*} \mathrm{p}<0.01$ düzeyinde anlamlıdır.

\subsection{Hiyerarşik Regresyon Analizi}

Araştırmanın bağımsız değişkeni algılanan örgütsel desteğin bağımlı değişken işe gömülmüşlük üzerindeki etkisinde kişi-iş uyumunun aracılık rolü Baron ve Kenny (1986) tarafından önerilen hiyerarşik regresyon analizi ile incelenmiştir (Tablo 8, 9, 10, 11).

Tablo 8'de yer alan hiyerarşik regresyon analizine ilişkin bulgular incelendiğinde; işe gömülmüşlük değişkeninin \%55.3'ü (Düz.R ${ }^{2}=.553 ; F=338,175 ; \mathrm{p}=.000$ ) ve kişi-iş uyumunun \%46.4'ü (Düz.R²=.464; F=237,577; 
$\mathrm{p}=.000$ ) algılanan örgütsel destek ile açıklanmakta olup regresyon modelleri anlamlı olarak tespit edilmiştir. Dolayısıyla Baron ve Kenny (1986) tarafından önerilen aracılık rolüne bakılabilmesi için gerekli olan ön koşullarının sağlandığı söylenebilir. Bu kapsamda gerçekleştirilen hiyerarşik regresyon analizi ve bulgularına göre; işe gömülmüşlüğün \%59.3'ünün algılanan örgütsel destek ve kişi-iş uyumu tarafından açılandığ1 (Düz.R $\left.{ }^{2}=.593\right)$ ve anlamlı ( $\left.\mathrm{F}=200,105 ; \mathrm{p}=.000\right)$ olduğu görülmektedir. Ayrıca algılanan örgütsel desteğin regresyon katsayısı olarak Beta değerinin $(\beta=744)$ analize aracı değişken kişi-iş uyumunun katılmasıyla ( $\beta=.553)$ azaldığı, ancak anlamlılığının ( $\mathrm{p}=.000)$ tamamen ortadan kalkmadığı belirtilebilir. Aynı şekilde aracı değişken kişi-iş uyumunda anlamlı ( $\mathrm{p}=.000)$ olduğu görülmektedir. Tüm bu bulgular 1şığında, "algılanan örgütsel desteğin işe gömülmüşlük üzerindeki etkisinde kişi-iş uyumunun aracılık rolü vardır" şeklindeki hipotez $\left(\mathrm{H}_{4}\right)$ "kısmi aracılık etkisi" olarak desteklenmektedir.

Tablo 8. Hiyerarşik regresyon analizine yönelik bulgular (1)

\begin{tabular}{|c|c|c|c|c|c|c|}
\hline Bağımsız/Aracı Değişken & Bağımlı Değişken & $\mathbf{R}^{2}$ & Düz.R² & $\mathbf{F}$ & $\beta$ & $\mathrm{p}$ \\
\hline Alg1lanan Örgütsel Destek & İşe Gömülmüşlük &, 554 &, 553 & $338,175^{*}$ & ,744 &, $000^{*}$ \\
\hline Alg1lanan Örgütsel Destek & Kişi-İş Uyumu & 466 & ,464 & $237,577^{*}$ & 683 &, $000^{*}$ \\
\hline Algilanan Örgütsel Destek & \multirow{2}{*}{ İşe Gömülmüşlük } & \multirow{2}{*}{, 596} & \multirow{2}{*}{,593 } & \multirow{2}{*}{$200,105^{*}$} &, 553 &, $000^{*}$ \\
\hline Kişi-İş Uyumu & & & & & 281 &, $000^{*}$ \\
\hline
\end{tabular}

${ }^{*} \mathrm{p}<0.01$ düzeyinde anlamlıdır.

Sobel $\mathrm{Z}=2.5886, \mathrm{p}=0.00$

Tablo 9' da yer alan hiyerarşik regresyon analizine ilişkin bulgular incelendiğinde; uyum boyutunun \%46.2'si (Düz. ${ }^{2}=.462 ; \mathrm{F}=235,120 ; \mathrm{p}=.000$ ) ve kişi-iş uyumunun \%46.4'ü (Düz. $\mathrm{R}^{2}=.464 ; \mathrm{F}=237,577 ; \mathrm{p}=.000$ ) alg1lanan örgütsel destek ile açıklanmakta olup regresyon modelleri anlamlı olarak tespit edilmiştir.

Tablo 9. Hiyerarşik regresyon analizine yönelik bulgular (2)

\begin{tabular}{lcccccc}
\hline Bağımsız/Aracı Değişken & Bağımlı Değişken & $\mathbf{R}^{2}$ & Düz.R & $\mathbf{F}$ & $\beta$ & $\mathbf{p}$ \\
\hline \hline Algılanan Örgütsel Destek & Uyum &, 464 &, 462 & $235,120^{*}$ &, 681 &, $000^{*}$ \\
\hline Algılanan Örgütsel Destek & Kişi-İş Uyumu &, 466 &, 464 & $237,577^{*}$ &, 683 &, $000^{*}$ \\
\hline $\begin{array}{l}\text { Algılanan Örgütsel Destek } \\
\text { Kişi-İş Uyumu }\end{array}$ & Uyum &, 518 &, 515 & $145,642^{*}$ &,- 463 &, $000^{*}$ \\
\hline
\end{tabular}

${ }^{*} \mathrm{p}<0.01$ düzeyinde anlamlıdır.

Sobel $Z=3.2965, p=0.00$

$\mathrm{Bu}$ kapsamda gerçekleştirilen hiyerarşik regresyon analizi ve bulgularına göre; uyum boyutunun \%51.5'inin algılanan örgütsel destek ve kişi-iş uyumu ile açıklandığı (Düz.R $\left.{ }^{2}=.515\right)$ ve anlamlı ( $F=145,642 ; p=.000$ ) olduğu görülmektedir. Algılanan örgütsel desteğin regresyon katsayısı olarak Beta değerinin $(\beta=681)$ analize aracı değişken kişi-iş uyumunun katılmasıyla $(\beta=.463)$ azaldığı, ancak anlamlılığının $(p=.000)$ tamamen ortadan kalkmadığ1 belirtilebilir. Aynı şekilde aracı değişken kişi-iş uyumunda anlamlı ( $\mathrm{p}=.000)$ olduğu görülmektedir. Tüm bu bulgular ışığında, "algılanan örgütsel desteğin işe gömülmüşlügü̆n uyum boyutuna etkisinde kişi-iş uyumunun aracılık rolü vardır" şeklindeki hipotez $\left(\mathrm{H}_{4 a}\right)$ "kısmi aracılık etkisi" olarak desteklenmektedir. 
Tablo $10^{\prime}$ da yer alan hiyerarşik regresyon analizine ilişkin bulgular incelendiğinde; bağ boyutunun \%21.9'u (Düz.R²=.219; F=77,645; p=.000) ve kişi-iş uyumunun \%46.4'ü (Düz.R²=.464; F=237,577; p=.000) algılanan örgütsel destek ile açıklanmakta olup regresyon modelleri anlamlı olarak tespit edilmiştir. Bu kapsamda gerçekleştirilen hiyerarşik regresyon analizi ve bulgularına göre; bağ boyutunun \%25.2'sinin algılanan örgütsel destek ve kişi-iş uyumu ile açıklandığı (Düz.R $\left.{ }^{2}=.252\right)$ ve anlamlı ( $F=46,875 ; p=.000$ ) olduğu görülmektedir. Algılanan örgütsel desteğin regresyon katsayısı olarak Beta değerinin $(\beta=471)$ analize aracı değişken kişi-iş uyumunun katılmasıyla $(\beta=.296)$ azaldığı, ancak anlamlılığının $(p=.000)$ tamamen ortadan kalkmadığı belirtilebilir. Aynı şekilde aracı değişken kişi-iş uyumunda anlamlı ( $\mathrm{p}=.000)$ olduğu görülmektedir. Tüm bu bulgular 1şığında, "algılanan örgütsel desteğin işe gömülmüşlüğün bağ boyutuna etkisinde kişi-iş uyumunun aracılık rolü vardır" şeklindeki hipotez $\left(\mathrm{H}_{4 \mathrm{~b}}\right)$ "kısmi aracılık etkisi" olarak desteklenmektedir.

Tablo 10. Hiyerarşik regresyon analizine yönelik bulgular (3)

\begin{tabular}{|c|c|c|c|c|c|c|}
\hline Bağımsız/Aracı Değişken & Bağımlı Değişken & $\mathbf{R}^{2}$ & Düz.R ${ }^{2}$ & $\mathbf{F}$ & $\beta$ & $\mathrm{p}$ \\
\hline Algilanan Örgütsel Destek & Bağ & ,222 & ,219 & $77,645^{*}$ & 471 &, $000^{*}$ \\
\hline Algilanan Örgütsel Destek & Kişi-İş Uyumu & ,466 & ,464 & $237,577^{*}$ & 683 &, $000^{*}$ \\
\hline Algilanan Örgütsel Destek & \multirow{2}{*}{ Bağ } & \multirow{2}{*}{,257 } & \multirow{2}{*}{,252 } & \multirow{2}{*}{$46,875^{*}$} & ,296 &, $000^{*}$ \\
\hline Kişi-İş Uyumu & & & & & 256 &, $000^{*}$ \\
\hline
\end{tabular}

${ }^{*} \mathrm{p}<0.01$ düzeyinde anlamlıdır.

Sobel $Z=3.2963, p=0.00$

Tablo 11'de yer alan hiyerarşik regresyon analizine ilişkin bulgular incelendiğinde; fedakârlık boyutunun \%43.3'ü (Düz.R²=.433; F=209,502; p=.000) ve kişi-iş uyumunun \%46.4'ü (Düz.R²=.464; F=237,577; p=.000) algılanan örgütsel destek ile açklanmakta olup regresyon modelleri anlamlı olarak tespit edilmiştir. Bu kapsamda gerçekleştirilen hiyerarşik regresyon analizi ve bulgularına göre; fedakârlık boyutunun \%44.4'ünün algılanan örgütsel destek ve kişi-iş uyumu tarafından açıklandığ 1 (Düz. $\left.R^{2}=.444\right)$ ve anlamlı $(F=109,964 ; p=.000)$ olduğu görülmektedir. Ayrıca algılanan örgütsel desteğin regresyon katsayısı Beta'nın değerinin $(\beta=660)$ analize aracı değişken kişi-iş uyumunun katılmasıyla $(\beta=.554)$ azaldığı, ancak anlamlılığının $(p=.000)$ tamamen ortadan kalkmadığı belirtilebilir. Aynı şekilde aracı değişken kişi-iş uyumunda anlamlı ( $\mathrm{p}=.000)$ olduğu görülmektedir. Tüm bu bulgular 1şığında, "algılanan örgütsel desteğin işe gömülmüşlüğün fedakârlık boyutuna etkisinde kişi-iş uyumunun aracılık rolü vardır" şeklindeki hipotez $\left(\mathrm{H}_{4 c}\right)$ "kısmi aracılık etkisi" olarak desteklenmektedir.

Tablo 11. Hiyerarşik regresyon analizine yönelik bulgular (4)

\begin{tabular}{|c|c|c|c|c|c|c|}
\hline Bağımsız/Aracı Değişken & Bağımlı Değişken & $\mathbf{R}^{2}$ & Düz.R ${ }^{2}$ & $\mathbf{F}$ & $\beta$ & $\mathrm{p}$ \\
\hline Algılanan Örgütsel Destek & Fedakârlık & ,435 & ,433 & $209,502^{*}$ & 660 &, $000^{*}$ \\
\hline Algılanan Örgütsel Destek & Kişi-İş Uyumu & ,466 & 464 & $237,577^{*}$ & ,683 &, $000^{*}$ \\
\hline Algılanan Örgütsel Destek & \multirow{2}{*}{ Fedakârlık } & \multirow{2}{*}{,448 } & \multirow{2}{*}{,444 } & \multirow{2}{*}{$109,964^{*}$} &, 554 &, $000^{*}$ \\
\hline & & & & & 155 &, $012^{* *}$ \\
\hline
\end{tabular}

${ }^{*} \mathrm{p}<0.01 ;{ }^{* *} \mathrm{p}<0.05$ düzeyinde anlamlıdır.

Sobel $\mathrm{Z}=2.4940, \mathrm{p}=0.05$ 


\section{SONUÇ ve TARTIŞMA}

Araştırmada çalışanların örgütsel destek algılarının işe gömülmüşlüğe etkisinde kişi-iş uyumunun aracılık rolünün emek yoğun bir sektör olan bankacılık sektöründe incelenmesi ve elde edilen bulgular ile hem ileride yürütülecek araştırmalar hem de sektörel düzenlemeler için yazına katkı sağlayacağı düşünülmektedir. Kuramsal ve görgül araştırmalar kapsamında araştırmanın amacı, algılanan örgütsel desteğin işe gömülmüşlük üzerindeki etkisinde kişi-iş uyumunun aracılık rolünün incelenmesidir.

Araştırmada, çalışanların örgütsel destek algılarının işe gömülmüşlük üzerindeki etkisinin anlamlı ve olumlu olduğu belirlenmiştir. Yazında bu bulgu ile aynı doğrultuda sonuçları olan bazı araştırmalar bulunmaktadır. Kesen ve Akyüz (2016) çalı̧̧malarında, algılanan örgütsel desteğin çalışanların bağlamsal performans algılarını ve işe bağlılıklarını artırdığını aynı zamanda çalışanların işe gömülmüşlük düzeylerini pozitif yönde etkileyerek işten ayrılma niyetlerini azalttığını belirtmektedirler. Aynı şekilde Aykan ve Akgül (2019) Kayseri lojistik sektöründeki çalışanlarla yaptıkları çalışmalarında, algılanan örgütsel desteğin çalışanların işe gömülmüşlük düzeylerini olumlu yönde etkilediğini vurgulamaktadırlar. Başka bir çalışmada Efe (2017), örgütsel desteğin bir sonucu olarak ortaya çıkan personel güçlendirmenin çalışanların işe gömülmüşlük düzeyini anlamlı ve pozitif olarak etkilediği sonucuna varmaktadır. Fatima, Shafique, Qadeer ve Ahmad (2015) öğretim üyeleri üzerine gerçekleştirdikleri çalışmalarında, algılanan örgütsel desteğin çalışanların işe gömülmüşlük düzeylerini olumlu ve güçlü yönde etkilediğini belirtmektedirler. Diğer taraftan algılanan örgütsel destek ile işe gömülmüşlügüun boyutları olan uyum, bağ ve fedakârlık üzerinde pozitif ve anlamlı bir etkinin olduğu ifade edilmektedir. Bu bağlamda örgütün çalışanlarına verdiği destek ve çalışanların bu desteği olumlu algılaması onların ekstra bir rol davranışı olan işe gömülmüşlük düzeylerini artırabileceğini ortaya koymaktadır.

Araştırmada, algılanan örgütsel desteğin kişi-iş uyumu üzerinde anlamlı ve pozitif bir etkisinin olduğu tespit edilmiştir. Yazında bu bulgu ile aynı doğrultuda bazı araştırma sonuçlarının olduğu ve bu bulgunun desteklendiği söylenebilir. Chen (2010) çalışmasında, algılanan örgütsel destek ile kişi-iş uyumu arasında pozitif ve anlamlı bir ilişki olduğunu tespit etmiştir. Ballout (2007) çalışmasında, kariyer başarısının en önemli öncülünün kişinin sahip olduğu özellikler ile işin özelliklerinin uyum içinde olması gerektiğini belirtmektedir. Ayrıca kişinin özelliklerinin yetersiz kaldığı veya artırılması gerektiğinde de örgütün ona her konuda destek olması kariyer başarısını artıracaktır. Dolayısıyla örgüt tarafından verilen desteğin çalışan tarafından olumlu algılanması onun işine olan uyumunu kolaylaştıracaktır. Aynı şekilde DeConinck, DeConinck ve Lockwood (2015) 98 satış yöneticisi ile gerçekleştirdikleri çalışmalarında, algılanan örgütsel destek ile kişi-iş uyumu arasında güçlü ve olumlu bir ilişkinin olduğunu vurgulamaktadırlar. Örgütün öncelikle yapılan işleri iyi analiz etmesi ve bu işlere uygun kişileri istihdam etmesi kişi-iş uyumu ve başarı açısından son derece önemlidir. Aynı zamanda çalışanların işleri ile ilgili istek ve ihtiyaçlarına destek olması da yine kişi-iş uyumu ve sergilenen performans açısından önemlidir. Bu bağlamda örgütün verdiği destek çalışanın işe olan uyumunu güçlendirebilir ve başarısını artırabilir. Aksi bir durumda ise çalışanın tükenmişliğini ve dolayısıyla da işten ayrılma niyetini artırabilir.

Araştırmada, kişi-iş uyumunun işe gömülmüşlük üzerinde anlamlı ve pozitif bir etkisinin olduğu belirlenmiştir. Araştırmanın bulgusu yazında yapılan diğer araştırmalar ile aynı doğrultuda değerlendirilmektedir. Dyk, Coetzee ve Takawira (2013) Güney Afrika'da bir hizmet işletmesindeki 206 çalışan ile gerçekleştirdikleri araştırmalarında, kişi-iş uyumunun işe gömülmüsşlük üzerinde olumlu bir etkisinin olduğunu, işe gömülmüşlüğün en önemli öncülünün kişi-iş uyumu olduğunu belirtmektedirler. Diğer taraftan Nguyen (2015) Vietnam'da 325 çalışan ile gerçekleştirdiği araştırmasında, çalışanların sahip oldukları özellikler ile işin özelliklerinin uyumlu olması onların işe gömülmüşlük davranışı sergilemelerine neden olduğunu belirtmektedir. Aynı şekilde işe gömülmüşlük, kişi-iş uyumunu, çalışanların örgüte bağlllığını ve işten ayrılması durumunda feda edilenlerin bileşimini ifade etmektedir (Aykan ve Akgül, 2019: 2719). Diğer taraftan Tabak ve Hendy (2016) çalışmalarında işe gömülmüşlük düzeyinin yüksek olması kişinin işi ile ne derece uyum sağladığı ile ilgili olduğunu vurgulamaktadırlar. Kişi-iş uyumu sağlanamadığı takdirde kişinin işe gömülmüşlük seviyesi düşük olabilir. Kanten vd. (2016) yapmış oldukları benzer bir çalışmada, iş özellikleri ile işe gömülmüşlük arasında pozitif ve anlamlı bir ilişki olduğu sonucuna ulaşmışlardır. Bu iki uyum çalışanların mutluluk düzeylerini de arttırmaktadır. Diğer taraftan kişi-iş uyumu ile işe gömülmüşlügüun boyutları olan uyum, bağ ve fedakârlık üzerinde anlamlı ve pozitif bir etkisinin olduğu görülmektedir. 
Araştırmanın bulgularına göre, algılanan örgütsel desteğin işe gömülmüşlük üzerine etkisinde kişi-iş uyumunun kısmi aracılık rolü olduğu tespit edilmiştir. Yazın taraması sonucunda bu değişkenler arasındaki aracılık rolünü inceleyen herhangi bir çalışmaya rastlanmamıştır. Bu durum araştırmanın yazına katkısı ve sonraki çalışmalara destek sağlaması bakımından önemlidir. Bulguya göre, algılanan örgütsel desteğin işe gömülmüşlük üzerindeki olumlu etkisi analize kişi-iş uyumu değişkeninin eklenmesiyle anlamlılı̆̆ını kaybetmemiş fakat olumlu etkisini azaltmıştır. Aynı şekilde algılanan örgütsel desteğin işe gömülmüşlüğün uyum, bağ ve fedakârlık boyutları üzerindeki olumlu etkisi analizlere kişi-iş uyumu değişkeninin eklenmesiyle anlamlılı̆̆ını kaybetmemiş fakat olumlu etkisini azaltmıştır. Bu bağlamda çalışanların işe gömülmüşlük düzeylerinin artırılması önemli oranda kişinin işi ile uyumu yakalayabilmesine bağlıdır. İşin özellikleri ile kişinin özellikleri (bilgi, beceri, yetenek vb.) ne kadar uyumlu olursa o kadar kişi işine bağlanabilir, ondan haz duyabilir, tatmin olabilir ve daha fazla işe gömülmüşlük davranışı sergileyebilir. Ancak bu durumun sürekliliğini sağlamak hiç de kolay bir konu değildir. Çalışanların devamlı olarak işe gömülmüşlük davranış sergilemeleri örgütün onlara destek sağlayıp sağlamadıkları ile de doğrudan bağlantılıdır. Örgüt, çalışanlarına ihtiyaç duyduğu veya kendisini işi ile ilgili bir konuda eksik hissettiği durumlarda destek vermesi işe gömülmüşlük davranışının sürdürülebilirliği için son derece önemlidir.

\section{KAYNAKÇA}

Afsar, B. ve Badir, Y. F. (2016). Person-organization fit, perceived organizational support, and organizational citizenship behavior: The role of job embeddedness. Journal of Human Resources in Hospitality $\mathcal{E}$ Tourism, 15(3), 252-278.

Akgündüz, Y., Güzel, T. ve Harman, S. (2016). Yöneticiye güven ve dağıtımsal adalet çalışanların işe gömülmüşlüğünü nasıl etkiler? Ege Akademik Bakış, 16(2), 351-362.

Akgündüz, Y. ve Şanl, S. C. (2017). The effect of employee advocacy and perceived organizational support on job embeddedness and turnover intention in hotels. Journal of Hospitality and Tourism Management, 31, 118-125.

Akkoç, İ., Çalışkan, A. ve Turunç, Ö. (2012). Örgütlerde gelişim kültürü ve algılanan örgütsel desteği iş tatmini ve iş performansına etkisi: Güvenin aracılık rolü. Celal Bayar Üniversitesi İktisadi ve İdari Bilimler Fakültesi Yönetim ve Ekonomi Dergisi, 19(1), 105-135.

Aktaş, M. (2011). Kültürel değerler ve kişi örgüt kişi iş uyumu ilişkisi: Kuramsal çerçeve. Selçuk Üniversitesi Sosyal Bilimler Enstitüsü Dergisi (26), 13-21.

Allen, D., Shore, L. M. ve Griffeth, R. W. (2003). The role of perceived organizational support and supportive human resource practices in the turnover process. Journal of Management, 29, 99-118.

Allen, D. G. ve Shanock, L. R. (2013). Perceived organizational support and embeddedness as key mechanisms connecting socialization tactics to commitment and turnover among new employees. Journal of Organizational Behavior, 34(3), 350-369.

Aykan, E. ve Akgül, H. (2019). Örgütsel desteğin, çalışanların işe gömülmüşlüğü üzerindeki etkisinde işgören avukatlığının aracılık rolü: Kayseri lojistik sektörü çalışanlarında bir uygulama. Manas Sosyal Araştırmalar Dergisi, 8(3), 2714-2733.

Ballout, H. I. (2007). Career success: The effects of human capital, person-environment fit and organizational support. Journal of Managerial Psychology, 22, 741-765.

Baron, M. R. ve Kenny, A. D. (1986). The moderator-mediator variable distinction in social pyschological research. conceptual, strategic and statistical considerations. Journal of Personality and Psychology, 51(6), 1173-1182.

Bergiel, E. B., Nguyen, V. Q., Clenney, B. F. ve Taylor, G. S. (2009). Human resource practices, job embeddedness and intention to quit. Management Research News, 32(3), 205-219.

Birsel, M., Börü, D., İslamoğlu, G. ve Yurtkoru, E. S. (2012). Job embeddedness in relation with different socio demographic characteristics. Öneri - Marmara Üniversitesi Sosyal Bilimler Enstitüsü Dergisi, 10(37), 5161. 
Bitmiş, G. M., Rodopman, B., Üner, M. M. ve Sökmen, A. (2015). Katılımcı liderliğin iş tatmini üzerindeki etkisi: örgütsel feda etmenin aracılık rolü. Gazi Üniversitesi İktisadi ve İdari Bilimler Fakültesi Dergisi, 17(1), 1-13.

Bredin, K. ve Söderlund, J. (2007). Reconceptualising line management in project based organisations. Personnel Review, 36(5), 818-833.

Büyükbeşe, T. ve Gökaslan, M.O. (2018). İşe gömülmüşlük, işe adanmışlık ve işten ayrılma niyeti ilişkisi: Bir alan çalışması. Mukaddime Dergisi, 9(2), 135- 153.

Cable, D. M. ve DeRue, D. S. (2002). The convergent and discriminant validity of subjective fit perceptions. Journal of Applied Psychology, 87(5), 875-884.

Candan, H. (2016). Türkiye'de akademisyenlerin işe gömülmüşlükleri ile performans ve tükenmişlikleri arasındaki ilişkinin incelenmesine yönelik bir araştırma. Journal of Business and Management, 18(3), 6880.

Chen, Y. (2010). Career success of knowledge workers: The effects of perceived organizational support and person- job fit. IBusiness, 2(4), 389-394.

Coetzer, A., Inma, C. ve Poisat, P. (2017). The job embeddedness-turnover relationship. Personnel Review, 46(6), 1070-1088.

Cook, K. S. \& Rice, E. (2003). Social exchange theory. (Ed: Delamater, J.) Handbook of social psychology. 53-76, New York: Kluwer.

Çelebi, N. ve Ülker, N. (2013). Yükseköğretim kurumlarında eğitimci bireylerin uyum algı ve davranışlarını etkileyen unsurlar. Eğitim ve Öğretim Araştırmaları Dergisi, 2(1), 127-139.

Çetin, F. ve Fikırkoca, A. (2010). Rol ötesi olumlu davranışlar kişisel ve tutumsal faktörlerle öngörülebilir mi? Ankara Üniversitesi SBF Dergisi, 65(4), 41-66.

Davis, D. ve Cosenza, R. M. (1998). Business research for decision making. Boston: Pws-Kent Publishing Company.

Deconinck, J. B., Deconinck, M. B. ve Lockwood, F. (2015). Influence of job fit, perceived support and organizational identificatoin in the sales force: An analysis of antecedents and outcomes. Archives of Business Research, 3(5), 51-59.

Duygulu, E., Çıraklar, N. ve Mohan, Y. (2008). Algılanan örgütsel destek, işe bağll1ık ve iş doyumunun örgütsel bağlllık üzerine etkisi. Celal Bayar Üniversitesi Sosyal Bilimler Enstitüsü Dergisi, 6(6), 108-128.

Dyk, V. J., Coetzee, M. ve Takawira, M. (2014). Satisfaction with retention factors as predictors of the job embeddedness of medical and information technology services staff. Southern African Business Review, 17(1), 57-75.

Edwards, J. R. (1991). Person-job fit: A conceptual integration, literatüre review and methodological critique. International Review of Industrial and Organizational Psychology, 6, 283-357.

Edwards, J. R. (1996). An examination of competing versions of the person-environment fit approach to stress. Academy of Management Journal, 39(2), 292-339.

Efe, E. G. (2017). Psikolojik personel güçlendirme ve işe gömülmüşlük halinin yeni ürün geliştirme performansı üzerindeki etkisi: Örgütsel adaletin ilımlaştırıcı rolü. Yayınlanmış yüksek lisans tezi, Nevşehir Hacı Bektaş Veli Üniversitesi Sosyal Bilimler Enstitüsü, Nevşehir.

Eisenberger, R., Huntington, R., Hutchison, S. ve Sowa, D. (1986). Perceived organizational support. Journal of Appliedpsychology, 71(3), 500-507.

Eisenberger, R., Cummings, J., Armeli, S. ve Lynch, P. (1997). Perceived organizational support, discretionary treatment, and job satisfaction. Journal of Applied Psychology, 82(5), 812-820.

Eisenberger, R., Jones, R. J., Aselage, J., Sucharski, I. L. ve Jones, J. R. (2004). Perceived organizational support, the employment relationship: examining psychological and contextual perspectives. (Ed. J. Coyle-Shapiro, L. Shore, and S. Taylor, \& L. Tetrick), Oxford University Press, 206-225. 
Farrell, M. A. ve Oczkowski, E. (2009) Service worker customer orientation, organisation/job fit and perceived organisational support. Journal of Strategic Marketing, 17(2), 149-167.

Fatima, M., Shafique, M., Qadeer, F. ve Ahmad, R. (2015). HR practices and employee performance relationship in higher education: Mediating role of job embeddedness, perceived organizational support and trust. Pakistan Journal of Statistics and Operation Research, 11(3), 421-439.

Gavino, C. M., Wayne, J. S. ve Erdoğan, B. (2012). Discretionary and transactional human resource practices and employee outcomes: The role of perceived organizational support. Human Resource Management, 51(5), 665-686.

Holtom, B. C., Mitchell, T. R. ve Lee, T. W. (2006). Increasing human and social capital by applying job embeddedness theory. Organizational Dynamics, 35(4), 316-331.

Hutcheson, J. M. (1999). An examination of three levels of person-environment fit. PhD dissertation, University of Houston, United States, Texas.

Kanbur, E. (2016). Algılanan örgütsel desteğin çalışanların iç girişimcilik performansları üzerindeki etkisinin incelenmesi. Kafkas Üniversitesi İ.̇.B.F. Dergisi, 7(14), 443-460.

Kanten, P., Kanten, S. ve Dündar, G (2016). Ücret tatmininin ve işin özelliklerinin işe gömülmüşlük üzerindeki etkisinde mutluluğun rolü. İşletme Araştırmaları Dergisi, 8(3), 64-88.

Kaya, Ş. D. (2013), Örgütsel vatandaşlık davranışı. Necmettin Erbakan Üniversitesi Sağlık Bilimleri Fakültesi Türk İdare Dergisi, 467, 265-287.

Kılıç, K. C. ve Yener, D. (2015). Birey-örgüt ve birey-iş uyumunun çalışanların iş tutumlarına etkisi: Adana ilinde bankacılık sektöründe çalışanlar üzerine bir araştırma. Çukurova Üniversitesi Sosyal Bilimler Enstitüsü Dergisi, 24(1), 161-174.

Kristof, A. L. (1996). Person-organisation fit: An integrative review of it's conceptualizations, measurement, and implications. Personnel Psychology, 49, 1-49.

Kristof, A. L., Zimmerman, R. D. ve Johnson, E. C. (2005). Consequences of individuals' fit at work: A metaanalysis of person-job, person-organization, person group, and person-supervisor fit. Personnel Psychology, 58(2), 281-342.

Kurtessis, J. N., Eisenberger, R., Ford, M. T., Buffardi, L. C., Stewart, K. A. ve Adis, C. S. (2015). Perceived organizational support: A meta-analytic evaluation of organizational support theory. Journal of Management, 43(6), 1-31.

Lauver, K. J. ve Kristof-Brown, A. (2001). Distinguishing between employees perceptions of person-job and person-organization fit, Journal of Vocational Behaviour, 59(3), 454-470.

Lee, T. W., Mitchell, T. R., Sablynski, C. J., Burton, J. P. ve Holtom, B. C. (2004). The effects of job embeddedness on organizational citizenship, job performance, volitional absences, and voluntary turnover. Academy of Management Journal, 47(5), 711-722.

Mitchell, T., Holtom, B., Lee, T., Sablynski, C. ve Erez, M. (2001). Why people stay: Using job embeddedness to predict voluntary turnover. Academy of Management Journal, 44(6),1102-1121.

$\mathrm{Ng}, \mathrm{T}$. W. H. ve Feldman, D. C. (2009). Occupational embeddedness and job performance. Journal of Organizational Behavior, 30, 863-891.

$\mathrm{Ng}$, T. W. H. ve Feldman, D. C. (2010). The impact of job embeddedness on innovation-related behaviors. Human Resource Management, 49(6), 1067-1087.

Nguyen, V. Q. (2015). Job characteristics, job embeddedness, and turnover intention: The case of Vietnam. Journal of International \& Interdisciplinary Business Research, 2(1), 1-13.

Oyler, J. D. (2007). Core self evaluations and job satisfaction: The role of organizational and communutiy embeddedness. Unpublished Doctoral Dissertation, Faculty of Virginia Polytechnic Institute and State University. 


\section{Mazıoğlu - E. Kanbur 12/2 (2020) 1639-1654}

Rhoades, L., Eisenberger, R. ve Armeli, S. (2001). Affective commitment to the organization: The contribution of perceived organizational support. Journal of Applied Psychology, 86(5), 825-836.

Saks, A. M. ve Ashforth, B. E. (1997). A longitudinal investigation of the relationships between job information sources, applicant perceptions of fit, and work outcomes. Personnel Psychology, 50, 395-426.

Shane, S. (2010). Born entrepreneurs, born leaders: How your genes affect your work life. North Carolina. Oxford University Press.

Sekiguchi, T. (2004). Person-organization fit and person-job fit in employee selection: A review of the literature. Osaka Keidai Ronshu, 54(6), 179-196.

Sekiguchi, T., Burton, J. P. ve Sablynski, C. J. (2008). The role of job embeddedness on employee performance: The interactive effects with leader-member exchange and organization-based self-esteem. Personnel Psychology, 61, 761-792.

Shore, L. M. ve Tetrick, L. E. (1991). A construct validity study of the survey of perceived organizational support. Journal of Applied Psychology, 76, 637-643.

Şanlı, S. C. (2016). İşgören avukatlığı ve alğlanan örgütsel desteğin çalışanların işe gömülmü̈şük ve işten ayrılma niyeti üzerine etkisi: Otel çalışanları üzerine bir araştırma. Yayınlanmış yüksek lisans tezi, Mersin Üniversitesi, Sosyal Bilimler Enstitüsü, Turizm İşletmeciliği Anabilim Dalı, Mersin.

Tabak, F. ve Hendy, N. T. (2016). Work engagement: trust as a mediator of the impact of organizational job embeddedness and perceived organizational support. Organization Management Journal, 13(1), 21-31.

TBB (2018). Türkiye Bankalar Birliği. https://www.tbb.org.tr/tr/bankacilik/banka-ve-sektor-bilgileri/verisorgulama-sistemi/illere-ve-bolgelere-gore-bilgiler/73.

Tseng, L. M. ve Yu, T. W. (2016). How can managers promote salespeople's person-job fit? The effects of cooperative learning and perceived organizational support. The Learning Organization, 23(1), 61-76.

Uçanok, B. (2008). Çalışma değerleri, çalışmanın merkeziliği ve kişi-iş uyumunun örgütsel vatandaşlık davranışı üzerindeki etkisi. Doktora Tezi. Marmara Üniversitesi Sosyal Bilimler Enstitüsü, İstanbul.

Ulutaş, M. (2010). Birey örgüt uyumu kuramı ve dalaman hava limanı çalışanları üzerine bir alan araştırması. Doktora Tezi, Selçuk Üniversitesi Sosyal Bilimler Enstitüsü, Konya.

Uysal-Irak, D. (2012). İşyerinde birey-çevre uyumu: kuramsal yaklaşımlar ve örgütsel psikolojideki yeri. Türk Psikoloji Yazllarl, 15(30), 12-22.

Whittaker, S. ve Marchington, M. (2003). Devolving HR responsibility to the line threat, opportunity or partnership? Employee Relations, 25(3), 245-261.

Yao, X., Lee, T. W., Mitchell, T. R., Burton, J. P. ve Sablynski, C. S. (Eds.). (2004). Job embeddedness: Current research and future directions. Information age publishing, 153-187.

Yazıcı, U. (2018). Kişi-iş uyumu ile proaktif kişilik ve proaktif çatışmanın akademik personel performansı üzerine etkisi: Bartın Üniversitesi örneği. Yüksek lisans tezi, Bartın Üniversitesi Sosyal Bilimler Enstitüsü, Bartın.

Yürür, Ş. (2005). Ödüllendirme sistemleri ile örgütsel adalet arasındaki ilişkilerin analizi ve bir uygulama. Yayınlanmamış Doktora Tezi, Bursa Uludağ Üniversitesi Sosyal Bilimler Enstitüsü, Bursa.

Zagenczyk, T. J. (2001). A social influence analysis of perceived organizational support. Dissertation of Doctor of Philosoph. The Katz Graduate School of Business, University of Pittsburgh. 